\title{
AN ANALYSIS OF ARCHETYPE OF MAIN CHARACTER JIM WHITE IN McFARLAND USA MOVIE
}

\author{
Raka Adam Pangestuํㅜ, Defi Julianti² \\ ${ }^{1,2}$ Department of English Literature, Faculty of Letters and Cultures Gunadarma University \\ Jl. Margonda Raya No.100 Depok 16424, Jawa Barat
}

Corresponding Author(S): rakaadam153@gmail.com

\begin{abstract}
:
The topic of this research is to analyze about archetype. Archetype is representation of metaphysical appeared from collective unconscious that can strengthen the personality of a person. This research's objective is analyzing the archetype of main character Jim White that can show the personality of the person itself based on archetype perspective and also find ego that appear in the main character. The theory that the researcher used is archetype theory that develop by Jung. This research uses descriptive qualitative research that used script dialogue of the movie as the data to find the result. The researcher found 22 data related to ego ( 4 data) and seven archetype that appeared, those are persona (5 data), shadow (2 data), anima (1 datum), hero (1 datum), great mother (2 data), wise old man ( 2 data) and self (5 data).
\end{abstract}

Keywords: McFarland USA, Archetype, Carl G Jung.

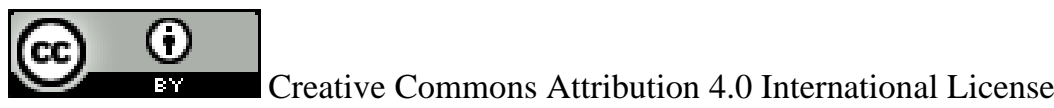

\section{INTRODUCTION}

Movie is an example of literary product that appears because of the development of the modern technology era. Usually, the movie is adapted from a written story such as a novel and short story or just came a fresh idea from the director to write down the story on the script play. According to Arsyad (2003. p, 45) movie is a group of several pictures that appeared in Frame, where frame by frame shown by projector lens with mechanical so the picture can be moved and looked alive.

From the definition of movie, the Jim character in McFarland USA movie is interesting to be analyzed. Based on the movie that adapted from the true story of his legacy, many aspects from Jim can be analyzed. The researcher wants to analyze the psychology condition of Jim and focusing on personality analysis based on the aspect of psyche ego and archetype that bring Jim to become success in his life at McFarland.

Carl Gustav Jung in Feist and Feist (2008) state in our mind there is circumstances that can lead our behavior, mind and feeling. Jung also called that as Psyche, which mean it used Jung for describing the whole personality of person. In his theory, he classifies the Psyche being a three level, there is (1) Conscious (Ego), (2) Personal Unconscious and 
(3) Collective Unconscious. Jung saw the ego as the center of consciousness, but not the core of personality. Ego is not the whole personality, but must be completed by the more comprehensive self, the center of personality that is largely unconscious. Based on the explanation, ego is certainly related to consciousness and it works on conscious level. According to Jung (in Feist \& Feist: 2008, p.103), conscious images are those that are sensed by the ego, whereas unconscious elements have no relationship with the ego. Ego is largely related about human desire, if human always following the ego, may it can be causing a bad thing if there is no consideration to aware for example arogant, greedy, anxiety and so on.

Jung believes and examines that the collective unconscious has much energy to affect the personality or person. The energy relates to a myth, archaic images and the experience passed down from ancestors that manifest and construct some pattern called Archetype. Archetype is the product that derived from collective unconsciousness. On the other hand, Archetype is a representation of metaphysical appeared from collective unconscious that can strengthen the personality of a person. Jung classifying Archetype in several elements, those are persona, shadow, anima and animus, self, the great mother, wise old man, hero. Those elements can show how the person personality in his or her life, also can be indication how the character of person in life. The reason why the researcher chose this topic because the topic was interested to be analyzed, especially the story of the movie itself is highlighting the journey story of main character which mean it can relate to the topic, that is to analyze person.

The researcher used McFarland USA movie as the object or the source of data and used the personality analysis and focus on Archetype theory or the collective unconscious to build a personality of a person by Jung. Aim of this research is to find archetype aspect and ego aspect that appear in main character Jim White. The purpose of the researcher made this research is to educate people about pychology power that can make a character of human called archetype. Also, the researcher took a several previous research as the references, namely, Heru Setiawan and Ririn Maulindan's research. Their research has a similar topic based on the topic of research that this research used. The kind of research also the same, that is qualitative research. The differences are located on the object of the research, the writers from previous research use novel as the object and source data for the research, meanwhile in this research the researcher use movie to take the data. In Heru's and Ririn's research, they only focused on several archetype based on Jung's theory those are, Persona, shadow, anima, animus and self, while in this research, the researcher focusing more element of archetype to analyze, those are, Persona, Shadow, Anima, Animus, Hero, Wise old man, Self and The great mother. At the end, this kind of research is can be important to people who lived in social, it may help you measure yourself in your envirotnment and indicator to improve yourself also introspection ourself for lived in social.

\section{METHOD}

In this research, the researcher uses descriptive qualitative method to identify the personality based on archetype theory in McFarland USA movie based on Jung. The researcher identifies personality or human problem and behavior of the character and researcher finds that descriptive qualitative research is the best method to this context. The source of data of this research is a movie entitled McFarland USA that released in 
2015 from Walt Disney Picture Production. Directed by Niki Caro, the duration is 125 minutes. The researcher used dialogues as data to be analyzed and discussed. The dialogues are taken from McFarland movie dialogue that is published in official website of www.Scripts.com and made by Christopher Cleaveland. The researcher used the dialogues in transcription to obtain information and gather the data to support this research. According to Sugiyono (2015, p.329) documentation technique is a way that used for collecting data and information from books, journals, document, figure and picture consist of the report and information that support the research. Based on that theory, this research used documentation technique in collecting the data, because the researcher used journals, books as reference to get information related to the topic.

\section{RESULTS AND DISCUSSION}

The researcher analyzed the ego and seven archetypes that appear in main character of the movie name Jim White. There are 22 data found related to the research topic. The researcher analyzed the persona of Jim as the teacher and humble man, shadow of Jim that related dark side of him that should not show in society that is anger and harshness, the anima of Jim that indicated by a bike that he ride, the great mother that appear by understanding and protecting instinct, the wise old man element that appear by his motivate words and the figure of teacher that he show, hero archetype that shown by how he save someone from dangerous situation and the last archetype, self that the process of him to become legacy and love his new society. Based on the analysis, it can be concluded, the researcher found ego and seven element of archetype that appear in the main character Jim White, those are persona, shadow, anima, wise old man, great mother, hero, and self.

a. Results

\begin{tabular}{|c|c|c|c|c|c|c|c|c|}
\hline $\begin{array}{l}\text { Data } \\
\text { No. }\end{array}$ & Ego & Persona & Shadow & Anima & $\begin{array}{c}\text { Great } \\
\text { Mother }\end{array}$ & $\begin{array}{c}\text { Wise } \\
\text { Oldman }\end{array}$ & Hero & Self \\
\hline 1 & & $\mathrm{~V}$ & & & & & & \\
\hline 2 & V & & & & & & & \\
\hline 3 & & V & & & & & & \\
\hline 4 & & & V & & & & & \\
\hline 5 & & V & & & & & & \\
\hline 6 & & $\mathrm{~V}$ & & & & & & \\
\hline 7 & & & & & & & & V \\
\hline 8 & V & & & & & & & \\
\hline 9 & & V & & & & & & \\
\hline 10 & V & & & & & & & \\
\hline 11 & & & & & & & V & \\
\hline 12 & & & & V & & & & \\
\hline 13 & & & & & & & & V \\
\hline 14 & V & & & & & & & \\
\hline 15 & & & V & & & & & \\
\hline 16 & & & & & & V & & \\
\hline 17 & & & & & & & & V \\
\hline 18 & & & & & & V & & \\
\hline 19 & & & & & V & & & \\
\hline 20 & & & & & & & & V \\
\hline 21 & & & & & $\mathrm{~V}$ & & & \\
\hline 22 & & & & & & & & V \\
\hline Total & 4 & 5 & 2 & 1 & 2 & 2 & 1 & 5 \\
\hline
\end{tabular}

Table 1 Data Result 
b. Data Analysis

Ego

(00:08:01 - 00:08:45)

Jim : We'll move to Bakersfield.

Cheryl : We cannot afford Bakersfield. Okay. Look at us We're living on a teacher's salary. I'm sorry. Babe, you said it yourself. This is the only job you could get.

Jim : $\underline{\text { I'm so sorry. }}$

From the fragment of conversation above, it can be seen the ego appear from Jim, the underline word indicated the ego of him that he want to move from Mcfarland because he did not like the town from the first day they move to Mcfarland, but the ego of Jim is counter by his wife Cheryl. Cheryl try to tell Jim the situation that they face right now and after that Jim become calm and apologize to his wife and try to accept the situation.

\section{Persona}

(00:09:23 - 00:09:31)

Maria Marsol : Jim, the new life science guy. And PE coach, and football. Jim

: That's right.

In this case the persona of main character Jim is a teacher, he is a new teacher who apply the job in public senior high school in town called McFarland. According to the conversation above, it is the first fragment of conversation that the teacher persona of Jim appear or the introduction Jim as the teacher. Cited from Raissa and Susanto on his journal said that persona is kind of mask that human must use in life to faces other people. Maria Masol, said if Jim is the new teacher in school, and the Jim confirmed it. Based on the dialogue above, it shown that Jim is a teacher in the school. "Jim, the new life science guy. And PE coach, and football." This dialogue from Maria Masol can be indicated she recognize Jim as a teacher. So in this conversation, the persona teacher of Jim appear. In this moment, Jim was a new teacher and want to apply as a life science teacher and phisycal education teacher at once at the school. This dialogue can be used for identification of Jim's persona as a teacher.

\begin{tabular}{|c|c|}
\hline $\begin{array}{l}\text { Shadow } \\
(00: 10: 3\end{array}$ & \\
\hline Camillo & $\begin{array}{l}\text { But then I read your file. Up in Saint Paul, you were } \\
\text { fired for verbally abusing your players. }\end{array}$ \\
\hline Camillo & : And a fight with the chairman of the school board? \\
\hline Jim & : Difference of opinion. \\
\hline Jim & : I lost my temper. It should never have happened. \\
\hline
\end{tabular}

As the definition of shadow itself is related about the dark side of person and it is also opposite with the persona, in this case from the dialogue above between Jim and Principal Camillo represent the accident that Jim had in the school that he worked before, few accidents that he did before mentioned in the dialogue is "verbally abusing to his 
students and fight with the chairman". In the dialogue show that Jim giving some reason about the accident and he said that that accident could not be happen again in the future. The shadow in that dialogue belongs to anger personality of Jim.

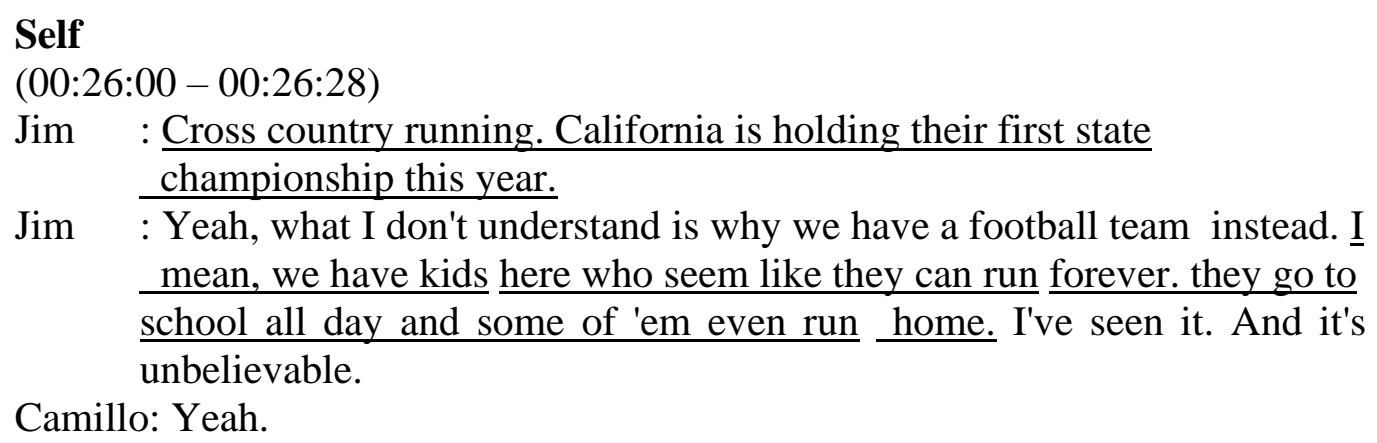

This conversation is a first the turning point process of Jim decide to become a cross country running coach in the school, "Cross country running. California is holding their first state championship this year." This sentence is showing that Jim suggest the principal about cross country running that makes him success become a cross country running coach. He saw the potential of students in the school who can become a great runner which can be seen at this sentence "I mean, we have kids here who seem like they can run forever. they go to school all day and some of 'em even run home." This identified the step of process of self realization of Jim to become a legacy in town and become the success cross country running coach.

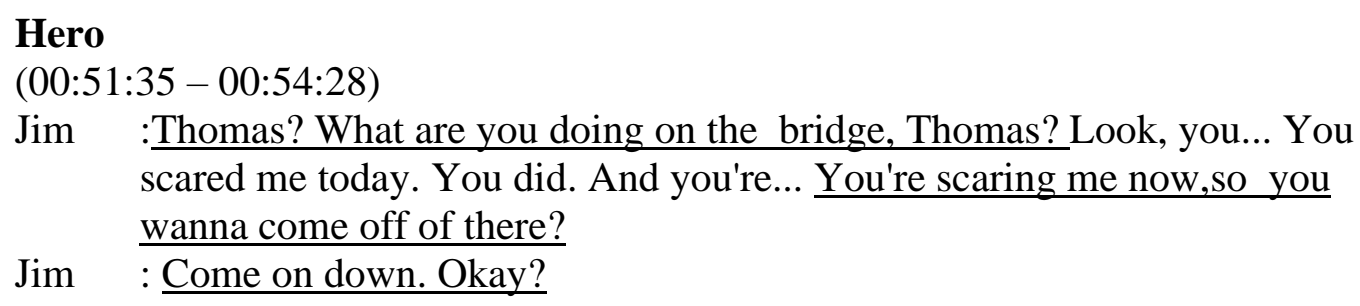

Based on the dialogue above, the situation is Thomas has a problem with his family, Jim accidentally saw Thomas sat on the edge of the bridge. Jim come near to Thomas while Jim worry if he will jump off the bridge. Jim told him the possibility if he jump off the bridge, Jim really won't lose him in the cross country team because he is the best runner at the team. By asking "Come on down. Okay?" he persuade Thomas to down and stay away from there for avoiding the dangerous situation, and then Jim tell him softly and pull him out of the bridge and save Thomas from a dangerous situation.

\author{
Anima \\ (00:56:55 - 00:57:08) \\ Jhonny : I don't know. Why you riding a Barbie bike? I bet you got the \\ matching doll house, too, huh? \\ Victor : Which one are you, White? Blanco Barbie?
}

Based on the dialogue above, the anima aspect that happen on Jim is represent when he ride a pink color Barbie bike. It shown in the fragment dialogue of Jhonny by ask Jim "Why you riding a Barbie bike?". Barbie is known as a doll that most of girl have 
it at their child moment, so Barbie is represent the feminine of girl. It can be concluded that Jim has an anima archetypes in his personality.

\section{Wise Old Man}

$(01: 21: 01-01: 21: 38)$

Jim

: Everybody, get in here. Come on. Danny, quit looking at the mountain. It's not going away and neither are you. You're gonna be all right. I've seen you out in the fields. You're an ox. So when you're in pain out there on this mountain, I want you to remember, I want you to remember,so is the guy next to you, and the guy in front of you This is gonna come down to which runners can handle the pain, So I want you to look at them, and I want you to look at each other and ask yourself, "Who's tougher?" Call it, Danny.

The fragment of Jim dialogue above it is show, how Jim try to make Danny who nervous at the time, Jim as a coach, behave like a wise old man. Jim motivate his team to stay focus for passing the qualified for the state championship. Figure of Jim is a definition of wise old man archetype, which can solve the problem and can help someone to find the solution by his advice and motivation.

\section{The great mother}

$(01: 36: 42-01: 37: 10)$

Jim : You got her? Jim : You'll go slow, right?

The situation of conversation above between Sammy, Jim, Julie, Thomas and Javi is happen when the party night of Jim's daughter that is Julie were offered by Javi to join the parade surrounding the city as the tradition at the city for whoever celebrate the birthday. There is indication from Jim who try to make sure if his daughter will be safe by asking "You got her?" to Thomas to make sure if he can protect Julie and affirmation question "You'll go slow, right?" to command Javi to drive slowly. As the explanation of the great mother archetype there is indication of mother archetype appear from Jim that is try to protect his daughter from any danger situation.

\section{CONCLUSION}

In this study, the result of the problem that analyzed by using archetype theory based on Carl Gustav Jung theory has found ego and seven archetypes appeared in Jim, those are persona, shadow, anima, wise old man, the great mother, hero and self. The number of data found are four data of ego, five data of persona, two data of shadow, one data of anima, two data of the great mother, two data of wise oldman, one datum of hero, and five data of self.

\section{REFERENCE}

Alwisol. (2009). Psikologi Kepribadian. Malang: Umm Press.

Arsyad, A. (2003). Media Pembelajaran. Jakarta: PT. Raka Grafindo Persada.

Atkinson, R. (1996). Introduction To Psychology. New York: Harcourt Brace College.

Badrun, A. (1983). Pengantar Ilmu Sastra (Teori Sastra). Surabaya: Usaha Nasional.

Caro, N. (2015). McFarland USA. USA: Walt Disney Picture.

Effendy, \& Uchjana, O. (1986). Ilmu Komunikasi. Remaja Karya. 
Endaswara, S. (2008). Metode Penelitian Psikologi Sastra. Yogyakarta: MediaPressindo.

Feist, J., \& Feist, G. J. (2008). Teori Kepribadian Theories of Personality. Jakarta: Salemba Humanika.

Harbunangin, B. (2016). Art ; Jung Seni Dalam Sorotan Psikologi Analitis Jung . Antara Publishing Jakarta Gramedia Jakarta Utama.

Hornby, A. S. (2006). Oxford Advanced Learner's Dictionary. Oxford University. Javandalasta, P. (2011). 5 Hari Mahir Bikin Film. Jakarta: Java Pustaka Group.

Koentjananingrat. (1993). Metode Penelitian Masyarakat. Jakarta: Gramedia.

Mas, M. (2007). Analysis of Mika's Character In Novel Kapak Written by Dewi Linggasari In The Archetype Perspective of Carl Gustav Jung An Instructional Of Literature. Yogyakarta: Sanata Dharma University.

Nurdayanti, C., Natsir, M., \& Lubis, I. S. (2020). The Archetype Analysis of Main Character In Hush, Hush Novel. Samarinda: Mulawarman University.

Packer, S. (2010). Superheroes and Superegos : Analyzing The Minds Behind The Mask. California: Praeger.

Raissa, T. Y., \& Susanto, A. (2020). Manifestasi Arketipe Tokoh Laissa Dalam Novel Dia Adalah Kakakku Karya Terre Liye : Analisis Psikologi Sastra. Jakarta : Universitas Nasional.

Rizakiah, S., Sili, S., \& Kuncara, S. D. (2018). An Analysis of Main Character In Warm Bodies Film Using Jung Theory of Archetypes. Samarinda: Mulawarman University.

Sarwono. (1987). Pengantar Psikologi Umum. Jakarta: Rajawali.

Semiun, Y. (2013). Teori-teori Kepribadian Analitik Kontemporer Vol.1. Yogyakarta: Kanisius.

Setiawan, H., \& Maulinda, R. (2020). Studi Arketipe Terhadap Tokoh Kiran Dalam Novel Tuhan Izinkan Aku Jadi Pelacur Karya Muhidin M Dahlan. Tanggerang: Pamulang University.

Sugiyono. (2013). Metode Penelitian Pendekatan Kuantitatif, Kualitatif dan R\&D. Bandung: Alfabeta.

Sukmadinata. (2006). Metode Penelitian Kuantitatif Kualitatif. Bandung: Graha Aksara.

Wellek, R., \& Waren, A. (1990). Teori Kesusastraan. Jakarta: PT Gramedia Pustaka Utama. 